\title{
A Cultural Man in the Market Jin's Art
}

\section{Jia Wu *}

Geely University of China, Chengdu, Sichuan 641423, China.

\begin{abstract}
Li Jin, a contemporary Chinese ink and wash artist, participated in the Eighth Five-Year Movement of Thought in China. Li Jin's art can be divided into three stages. The first stage is during the Eighth Five-Year Movement, Chinese artists turned to Western modern art and post-modern art. The process of learning, and Li Jin's artistic style presents expressionism, such as Tibetan group paintings. And the second stage is that after 1989, Chinese art has undergone a new turning point. The lofty and philosophical avant-garde art of the 1980s has declined, because intellectuals throughout China clearly understand that the right to speak is always in the hands of the power, and power is Justice and discourse, the brush for writing history is not for the general public, so after 1989, there was a gap in culture and a decline in spirit. He spoke with a hippie smile and a cynical attitude, so cynical realism, political pop art, female art, with the emergence of gaudy art, the artist's perspective has changed from a macro perspective to a daily trivial matter, generalized and secularized. At this stage, Li Jin's art expresses the things of family life, presenting private space. The third stage is after 2000. Due to the changes of the times, market capitalism has allowed Chinese contemporary art to gain some official status. In this modern China where consumerism and pragmatism are popular, Li Jin directly intervenes in his self-image to express his feelings and memories of this social fragment. Even though there are many personal sensibility elements, the artist is using his own eyes and beating heart to feel that it is a kind of reality, not the real nihility in the socalled history textbook. These are the three stages of Li Jin's art. The main topic of this thesis is Li Jin's daily expressions based on the theme of gourmet beauties from the 1990s to the present, writing market culture from the first perspective of ordinary people. The thesis is divided into three parts: the first part is to discuss Li Jin's expression of beautiful food. The second part discusses Li Jin's perfect integration of traditional ink painting and contemporary society. The third part is to discuss the turning and criticism of Li Jin's art in the global context.
\end{abstract}

Keywords: Ink and Wash Art; Market Culture; Beautiful Cuisine.

\section{The "Eat and Sexuality" of a Big Man}

The first impression of Li Jin's art is life-oriented and market-oriented. Chicken legs, radishes, garlic, pork belly, fish and other home-cooked dishes are all presented in Li Jin's paintings. He pays attention to homework and market culture, but Li Jin's art works are not so realistic, but have a liberal expression. The work has a sense of richness and appetite. Before the reform and opening up, China was poor and white, and experienced material scarcity. Therefore, material things are a sense of desire for Chinese people, both physically and psychologically. This "illness" is imprinted in the bones and souls. After opening up, China has entered a consumer society, and the problem of material food and clothing has been mostly solved. However, in the daily materialism, the insecurities of hunger and thirst are still unconsciously pulling the public, supported by the possessive desire for satiety ${ }^{[1]}$. Moving people forward brings happiness and beauty. The delicacies in Li Jin's works have a sense of spiritual satiety, but behind this rich food is a lack of meaning. There is a lot of food that is impenetrable, but there is no open-mindedness. This is also the artist's personal artistic transformation of the state of a certain historical stage. Since 2005, Li Jin has presented a lot of self-portraits in his paintings. Li Jin, who is loose by nature, loves freedom, loves food, and loves beautiful women, looks a little cynical, and his character is reflected in the characters in his artistic creations. The characters in the works are a bit ignorant, slightly drunk, and immersed in their own world, their eyes are in a trance, no matter of the world, happy and free. He painted himself and his wife, and his facial features and physical parts were specially artistic. When many viewers look at Li Jin's figure paintings, they feel that it is a kind of kitsch art that is difficult to be elegant and vulgar. Li Jin's paintings are indeed expressing the love life in daily private space, but the expressions of the characters are also in line with the artist's self-cognition, and he is ignorant of art, life, and life. Life is like this. Face it according to your own attitude and way, and Li Jin's women are also different. He treats them with looking up. He is not as overwhelmed as the previous lady pictures, with the feeling of frailty and melancholic voice. The sense of classicism is the real artistic expression of the daily state. This is Li Jin's self-conversation with art, and it is also the artist's personal intervention in contemporary society to make a real voice. The so-called culmination of vulgarity is elegance, and there is too little art that appreciates both elegance and vulgarity, and Li Jin's works happen to do just that. Art is not to be high above and not to be looked up to, but to express with a true attitude of self, which will exude real power.

Copyright (C) $2020 \mathrm{Jia} \mathrm{Wu}$

doi: 10.18282/1-e.v9i4.1731

This is an open-access article distributed under the terms of the Creative Commons Attribution Non-Commercial License (http://creativecommons.org/licenses/by-nc/4.0/), which permits unrestricted non-commercial use, distribution, and reproduction in any medium, provided the original work is properly cited. 


\section{The perfect integration of traditional ink painting and contemporary society}

Li Jin is a contemporary ink and wash artist. Even if his works are recognized by official and international galleries, in the recognition of traditional Chinese painting artists, this is just a commercial hype under market capital. This is a recognition of money, not a recognition of artistic status. In fact, the transformation of Chinese painting is nothing new. From the revolutionary art that began on the May Fourth Movement and the artistic standards of the Cultural Revolution, to the eighth-five ideological trend, Li Xiaoshan believed that Chinese painting has reached its end. The transformation of Chinese painting is always going on. How to change, how to change, these are the main points we have discussed. After the change, the traditional school thinks that it is nondescript. After the change, the innovation school thinks that it is old and stubborn, and the old wood cannot be carved. Moreover, Chinese artists and critics believe that we should have our own painting evaluation system and rules. These kinds of debates and the smoke of no war have always existed in the circle of Chinese artists. As for Li Jin's art, the perfect combination of traditional Chinese painting art and contemporary society creates a new era. The system and standards of traditional Chinese painting have been mature, and the cultural, spiritual, and philosophical concepts in it have also profoundly affected the artistic development of Chinese artists ${ }^{[2]}$. Learn to use. But the times have changed, the vicissitudes of life, the former prosperity of the Xia, Shang and Zhou Dynasties, the imposing and ancient Qin and Han, the Wei Jin style, the radiant and demanding Tang Dynasty, the landscape of the Song Dynasty where everything is calm and content, the Yuan, Ming and Qing of the literati Sao Ke opera novels . Just as Mr. Wang Guowei once said: "Every generation has a generation of literature, and no successor." Now, we can create from our own perspective what belongs to our era. Innovate on the basis of predecessors. The magnanimity and loftiness of the ancients cannot be copied in this era. We belong to this era instead of reminiscing about the past things that do not belong to our memory. Li Jin's painting is based on the artistic language of not abandoning the traditional pen and ink, and he understands and recreates all the changes in this era and all the influences on self-growth. Draw paintings belonging to the Li Jin era. Not the art of the ancients. Therefore, since the 1990s, Li Jin has changed his perspective to family daily life, gourmet beauty, the so-called "food and color," different characters express their ideas in different ways, and behind the art is the embodiment of a person's value. The ancients just put the individual behind the scenes, expressing his contemplation and contentment with all things in a way of entrusting things, requiring spectators to contemplate and look up. Li Jin puts the individual in front of the screen, and all the emotions, emotions, emotions, sorrows, sorrows and joys are displayed vividly, frankly and openly, without guessing, and the dialogue is equal. Each has its own era, and different standards and moods create different styles. There is no need to use the ancients' set of rules to make a high-level evaluation.

\section{The turn and criticism of Li Jin's art in the global context}

In the global context, how is the integration and cooperation between Chinese art and world art, and how the ancient Eastern civilization exudes its unique charm and difference from the other. It is said that the Chinese should create their own artistic evaluation system so that the world will abide by our rules, not the rules of the game in the West. It's good to have such an idea, but to be independent from the world ${ }^{[3]}$. This world is not his, nor mine, but ours. We are on a planet, and it is especially important to have our own characteristics, but we are not aloof. In such a global village with information explosion, Chinese art is different from others. This is because every country and nation has a unique taste, that is, culture. Li Jin was born and grew up in Tianjin, a combination of Chinese and Western culture. He was influenced by Yangliu Youth's paintings, and the culture of Tianjin also cultivated Li Jin's unique artistic temperament. The artist accepts his own culture, and uses artistic methods to engage in dialogue with himself and life. The daily depiction of life in the city is tireless. Life is so plain, but there are many different flavors. The tastes are different and different. It is wonderful to be able to live life through and emit a unique light. Li Jin is such a daily citizen, with unique culture and unique feelings, creating unique art that will resonate with the audience. Such Li Jin occupies his place in Chinese contemporary art, and he also has a monarchy in the world. And Li Jin's art is a kind of ethical turn, the voice, fragments, sensibility, but so real of the literati.

\section{References}

[1] Lu Peng. Chinese Contemporary Art History: 2000-2010 [M]. Shanghai People’s Publishing House, 2014.

[2] Wu Hung. Take his own way-Wu Hung on Chinese contemporary artists[M]. Lingnan Fine Arts Publishing House, 2008

[3] Wu Hong. Works and Exhibition: On Chinese Contemporary Art [M]. Lingnan Fine Arts Publishing House, 2005. 